\title{
EFFECT OF "MOST-FAVOURED-NATION" CLAUSE IN COMMERCIAL TREATIES*
}

The most-favored-nation clause is one which has become customiry to insert in treaties of commerce, providing that, if any reductions of tariff or other advantages are granted by either cocontracting State to any third State, the other shall have the benefit of it.

The forms of most-favored-nation clauses vary considerably. Thus that of the Treaty of Commerce and Navigation between Great Britain and France of February 28th, 1882, runs:-"Each of the High Contracting Partics engages to give the other immediately and unconditionally the benefit of every favor, immunity, or privilege in matters of commerce or industry which may have been or may be conceded by one of the High Contracting Powers to any third nation whatsoever, whether within or beyond Europe."

The British Treaty of Commerce with Honduras of January 2Ist, IS87, provicles:- "The High Contracting Parties agree, that in all matters relating to commerce and navigation, any privilege, faver, or immunity whatever which either contracting party has actually sranted or may hercafter grant to the subjects or citizens of any other State shall be extended immediately and unconditionall $y$ to the subjects or citizens of the other contracting party; it being their intention that the trade and navigation of each country shall be placed in all respects by the other on the footing of the most favored nation" (Article I).

The Anglo-Roumanian Treaty of August I3th, I892:- "The subjects, vessels, and goods, produce of the soil and industry of each of the two High Contracting Parties shall enjoy in the dominions of the other all privileges, immunities, or advantages granted to the most favored nation" (Article I).

In Europe such clauses have in practice been uniformly treated as applying to all reductions of tariff without distinction. ${ }^{1}$ The United States' interpretation, on the other hand, distinguishes between reductions of a general character and reductions made specifically in return for reductions by another State. The latter do not, according to this interpretation, come within the operation of the

*Paper read at a conference of the International Law Association, at Portland, Maine, August 3, Igo7.-[ED.] 
clause, and a co-contracting State is only entitled to obtain extension of them to itself by granting similar concessions. In other words, concessions to any co-contracting State are only allowerl gratuitously to a third co-contracting State, when nothing is given for them, the clause not covering advanages granted in return for advantages.

In a dispatch of July I7th, 1886, to the American Minister in China, Mr. Bayard, explained the American view in the following terms:-

"In its commercial aspects the expediency of an unqualified favored-nation clause is questionable. The tendency is towards its formal qualification, by recognizing in terms, what most nations hold in fact and in practice, whether the conclition be expressed in the clause or not, that propinquity and neighborliness may create special and peculiar terms of intercourse not equally open to all the workl; or by provicling that the most-favored treatment, when hased on special or reciprocal concessions, is only to be extended to other Powers on like conditions."?

This is still the United States vicw, as is set out in a luminous article in the November (IgO5) number of the North American Review, on "Alternative of Reciprocity Treaties, or a Double Tariff," by Mr. John Osborne, chief of the Burcau of Trade-Relations, State Department, and late Secretary of the Reciprocity Commission, a gentleman eminently competent to describe the contemporary American standlpoint. Mr. Osborne maintains that "it is evident that the gratuitous extension to third Powers of commercial advantages exchanged in reciprocity between two countrics is absolutely inconsistent with the true principles of reciprocity as understood in the United States; it would not only seriously impair and even tend to destroy the valute of the original grant, but it would also involve

I. Special arrangements, based on geographical contiguity, might, nevertheless, and with reason, be held not to be of general application.

2. See Wharton's Digest on the Intcrnational Law of the United States, sec. 134. It is interesting to recall the interpretation by the United States Government of the 8th Article of the Convention for the cession of Louisiana, providing that after the expiration of twelve years from the date of that Treaty, the ships of France should be treated upon the footing of the mostfavored nations in the ports of the ceded territory. It was contended by France that this was an absolute agreement, irrespective of the conditions upon which favors were granted to other nations, and that, therefore, when a favor should be granted to another nation for a consideration (reciprocal or otherwise), or upon a condition, France was entitled to enjoy the same favor without consideration or condition. This was denied by the United States. The claim was abandoned by France in the Treaty of $18_{3} I$ (Bancroft Davis, Treaties of the United States, 1873, p. 127). 
duty reductions upon the entirety, or, at least, the bulk of importations from the world, of the articles of merchandise affected, thus constituting a serious sacrifice in national revenues."

This is an argument of policy, and not one, properly speaking, of interpretation or construction. No strictly juridical argument can be urged in support of the American view. Whether a reduction "bought," as it were, by a counter-reduction is affected by a "mostfavored-nation" clause, depends, from a juridical point of view, solely on the wording of the clause.

There seemed to be a possibility that this would become the judicial attitude in America under the decision of the United States Supreme Court in Bartram v. Robertson, in which the Supreme Court held that brown and unrefined sugars, the produce and manufacture of the Island of St. Croix, a Danish possession, were not exempt from duty under the Treaty with Denmark, though similar goods from the Hawaiian Islands were thus exempt. The first Article of the Treaty with Denmark provided that the contracting parties should not grant "any particular favor" to other nations, in respect to commerce and navigation, which should not immediately become common to the other party, who should enjoy the same freely if the concession zere freely made, and upon allowing the same compensation if the concession were conditional. Article IV provided that no higher or other duties should be imposed by either party on the importation of any article of its produce or manufacture, into the country of the other party, than were payable on like articles, being the produce or manufacture of any other foreign country. The Supreme Court held that-"These stipulations, even if conceded to be self-executing by the way of a proviso or exception to the general law imposing the duties, do not cover concessions like those made to the Hawaiian Islands for valuable consideration. They were pledges of the two contracting parties, the United States and the King of Denmark, to each other, that in the imposition of duties on goods imported into one of the countries which were the produce or manufacture of the other, there should be no discrimination against them in favor of goods of like character imported from any other country. They imposed an obligation upon both countries to avoid hostile legislation in that respect. But they were not intended to interfere with special arrangements with other countries founded upon a concession of special privileges."

The last sentence in the above quotation might have been more explicit, but the general tenor of the judgment seems favorable to a strict application of the tenor of the clause. 
The subject a few months later came up again in the same Court in Whitney v. Robertson (Supreme Court of the United States, I887, 124 United States, I90), when the official view, on the contrary, was strongly endorsed. The plaintiffs in the new action were merchants doing business in the city of New York. They imported a large quantity of sugars, produce of the island of San Domingo, similar in kind to sugars produced in the Hawaiian Islands, which were admitted free of duty under a Treaty with the Government of the latter. This Treaty provided for the importation into the United States, free of duty, of various articles, "the produce and manufacture of those islands, in consideration, among other things, of like exemption from duty, on the importation into that country, of sundry specified articles which are the produce and manufacture of the United States." The first two Articles of the Treaty, which recited the reciprocal engagements of the two countries, declared that they were made in consideration "of the rights and privileges" and "as an equivalent therefor," which the one conceded to the other. The plaintiffs relied for a like exemption of the sugars imported by them from San Domingo upon Article IX of the Treaty with the Dominican Republic, which is as follows: No higher or other duty shall be imposed in the importation into the United States of any article of growth, produce, or manufacture of the Dominican Republic, or of her fisheries; and no higher or other duties shall be imposed on the importation into the Dominican Republic of any article the growth, produce, or manufacture of the United States or their fisheries, than are or shall be payable on the like articles, the growth, produce, or manufacture of any other foreign country, or its fisheries." Counsel for the plaintiffs contended that the omission from the Treaty with the Republic of San Domingo of the DanishAmerican distinction between free concessions, and concessions upon compensation, precluded any concession in respect of commerce and navigation by the United States Government to another country without that concession being at once extended to San Domingo. The Supreme Court, however, held that the absence of this provision did not change the obligations of the United States; that Article IX of the Treaty with San Domingo was "substantially like Article IV in the Treaty with the King of Denmark." It was a pledge by the contracting parties that there should be no discriminating legislation against the importation of articles which were the growth, produce, or manufacture of their respective countries, in favor of articles of like character imported from any other country, but "it had no greater extent." "It was never designed to prevent 
special concessions, upon sufficient considerations, touching the importation of specific articles into the country of the other." "It would require the clcarest language to justify a conclusion that the United States Government intencled to preclude itself from such engagements with other countriss, which might in the future be of the highest importance to its interests."

With all respect to the great anthority of the decisions of the United States Supreme Court, the language of the Treaty in question seems of the clearest, and diamctrically opposed to its ruling.

The Treaty regulating the trade relations between Great Britain and the United States (July $3 \mathrm{rd}$, I8I5), continued in force and reported in an official return to the British Parliament, Commercial No. 9, 1903, to be in operation between two countries down to July Ist, I903, is practically in the same terms, providing that "no higher or other duties shall be imposed on the importation into the territories of His Britannic Majesty in Europe of any ar ticles of growth, produce, or manufacture of the United States, and no higher or other duties shall be imposed in the importation into the United States of any articles, the growth, produce, or manufacture of His Britannic Majesty's territories in Europe, than are or shall be payable on the like articles, being the growth, produce, or manufacture of any foreign country" (Article II).

This, I say, is practically the same wording as that which the United States Supreme Court holds not to cover special reductions made in return for special privileges.

The form adopted in the Treaty between Great Britain and Uruguay of July $I_{5}$ th, I899, leaves nothing to construction; it specifically restricts the application of the clause:-

"It was also agreed that the stipulations contained in the Treaty which is to be renewed do not include cases in which the Government of the Oriental Republic of Uruguay may accord special favors, exemptions, and privileges to the citizens or products of the United States of Brazil, of the Argentine Republic, or of Paraguay in matters of commerce. Such favors cannot be claimed on behalf of Great Britain on the ground of most-favored-nation rights as long as they are not conceded to other States. It is, nevertheless, understood that the said special favors, exemptions, and privileges shall not be capable of application to products similar to those of Great Britain, nor be extended to navigation."

The same may be said of the Franco-German Treaty of Frankfort (May Ioth, I87I). Article II of that Treaty provides as follows:-

"The treaties of commerce with the different States of Germany having been annulled by war, the French and German Governments 
will base their commercial relations upon the system of reciprocal treatment on the footing of the most favored nation.

"This rule shall not apply, however, to the favors which either of the contracting parties, by commercial treaties, has granted or shall grant to States other than the following:-England, Belgium, Holland, Swizerland, Austria, and Russia. . . .

"Nevertheless, the French Government reserves to itself the faculty to establish on German vessels and their cargoes tonnage and flag duties, under reserve that these duties shall not be higher than those which are imposed upon vessels and cargoes of the abovementioned nations."

The German-Austro-Hungarian Treaty of Commerce of December 6th, 189I, amended and completed by that of January 25th, I905, provides that no more favorable conditions in respect of "import, export, or transit" duties shall be granted by either contracting party to a third Power than are accorded to the other party, and that any concessions of this kind made to a third Power shall at once be applied to the other (Art. II), any dispute relating to this provision to be referred to arbitration (Art. XXIII). This seems equally clear in the contrary sense.

In Europe the American view has found some supporters in theory. Thus the distinguished French writer, $M$. Hautefeuille, in answer to the question of whether the condition of being treated as the most favored nation only carried the advantages existing at the time of the signature of the Treaty, or comprised those which should be subsequently conceded to another State, answered that the clause must be considered as implying everything that existed at the moment when signed, but that it could not be considered to extend to anything later in date. ${ }^{3}$ "Prof. F. de Martens considers that a distinction must be made between cases in which a commercial advantage is granted purely and simply, and cases in which there is simply an exchange of bons procédés or a dédommagement. "In the former alone have other States a right to claim the same advantage. To grant it in the second would be contrary to the principle of the reciprocity of commercial obligations."4

3. Histoire des Origines, \&c. (1858), ii. pp. 300,301 .

4. Droit International (1886), ii. p. 322. "At the present day, when national interests are so tangled and complex," says M. Lehr, "it is always a serious matter to bind oneself in advance by a clause which is vague and general, and the eventual bearing of which cannot be estimated. There have been several instances in the course of the last few years in which a Power in the negotiation of a Treaty has been under the necessity of refraining from granting concessions, because being extended by virtue of ithe clause, without any compensation whatever to a whole series of other countries, they would have been disastrous to the national industry."-See Ernest Lehr, Revue de Droit International, 1893, p. 31 s. 
It is evident that it will be necessary in future treaties of commerce to be careful to provide against the possibility of a construction which might frustrate the very objects for which most-favorednation clauses are resorted to, namely, to prevent any third Power from enjoying special advantages. Meanwhile the interest of stable international relations requiring that the sense of the existing terminology of the clause should be defined, this Association might adopt the following resolution or view on the subject:-

"Whereas any varying interpretation of the most-favored-nation clause gives rise to instability in the trade relations of co-contracting countries, it is suggested that any State holding itself to be aggrieved by any such varying interpretation should be entitled to cite the co-contracting party before the Hague Court, and that the jurisdiction of the said Hague Court in all such matters should be accepted without reservation."

Sir Thomas Barclay. 